\title{
Genetics in eating disorders: extending the boundaries of research
} Genética em transtornos alimentares: ampliando os horizontes de pesquisa

\author{
Andréa Poyastro Pinheiro, 1,2 Patrick F Sullivan, ${ }^{1,3}$ Josue Bacaltchuck, ${ }^{2}$ \\ Pedro Antonio Schmidt do Prado-Lima, ${ }^{4}$ Cynthia M Bulik ${ }^{1}$
}

\begin{abstract}
Objective: To review the recent literature relevant to genetic research in eating disorders and to discuss unique issues which are crucial for the development of a genetic research project in eating disorders in Brazil. Method: A computer literature review was conducted in the Medline database between 1984 and may 2005 with the search terms "eating disorders", "anorexia nervosa", "bulimia nervosa", "binge eating disorder", "family", "twin" and "molecular genetic" studies. Results: Current research findings suggest a substantial influence of genetic factors on the liability to anorexia nervosa and bulimia nervosa. Genetic research with admixed populations should take into consideration sample size, density of genotyping and population stratification. Through admixture mapping it is possible to study the genetic structure of admixed human populations to localize genes that underlie ethnic variation in diseases or traits of interest. Conclusions: The development of a major collaborative genetics initiative of eating disorders in Brazil and South America would represent a realistic possibility of studying the genetics of eating disorders in the context of inter ethnic groups, and also integrate a new perspective on the biological etiology of eating disorders.
\end{abstract}

Keywords: Anorexia nervosa; Bulimia nervosa; Eating disorders; Genetics; Molecular genetics

\begin{abstract}
Resumo
Objetivo: Revisar a literatura atual concernente à pesquisa genética em transtornos do comportamento alimentar e discutir questões relevantes ao desenvolvimento de um projeto de pesquisa genética nessa área no Brasil. Método: A revisão realizada utilizou a base de dados Medline, no período de 1984 a maio de 2005, com os seguintes termos de busca: "anorexia nervosa", "bulimia nervosa", "eating disorders", "binge eating disorder", "family studies", "twin studies", "molecular genetics studies". Resultados: Os dados atuais apontam para uma contribuição relevante dos fatores genéticos na suscetibilidade à anorexia e à bulimia nervosa. A pesquisa genética com populações miscigenadas deve levar em consideração o tamanho da amostra, a densidade de genotipagem e a estratificação populacional. Através de "admixture mapping" é possível estimar a estrutura genética destas populações e localizar genes relacionados à variação étnica de doenças ou traços de interesse. Conclusões: O desenvolvimento de uma grande iniciativa de colaboração em genética de transtornos alimentares no Brasil e na América Latina viabilizará estudar os fatores genéticos em transtornos do comportamento alimentar no contexto de grupos inter-étnicos, e integrar uma nova perspectiva biológica à etiologia destes distúrbios.
\end{abstract}

Descritores: Anorexia nervosa; Bulimia nervosa; Transtornos da alimentação; Genética; Genética molecular

1 Department of Psychiatry, University of North Carolina, Chapel Hill, NC

2 Department of Psychiatry, Escola Paulista de Medicina, Universidade Federal de São Paulo (UNIFESP), São Paulo (SP), Brazil

3 Department of Genetics, University of North Carolina, Chapel Hill, NC

4 Behavioral Neurobiology Research Group, Biomedical Research Institute, Pontifícia Universidade Católica do Rio Grande do Sul (PUC-RS), Porto Alegre (RS), Brazil

Financing: Dr. Andréa Poyastro Pinheiro received financial support from the Conselho Nacional de Desenvolvimento Científico e Tecnológico (CNPQ)

Conflict of interests: None

Submitted: 14 September 2005

Accepted: 24 January 2006

\section{Correspondence}

Andréa Poyastro Pinheiro

Department of Psychiatry, CB\#7160

Neurosciences Hospital, University of North Carolina

Chapel Hill, NC, 27599-7264, USA

Phone: +919-966-5261 Fax: +919-966-5628

E-mail: andrea_pinheiro@med.unc.edu 


\section{Introduction}

Eating disorders - psychiatric disorders characterized by severe disturbances in eating behavior that typically have onset during late adolescence and young adulthood - are divided into three major types: anorexia nervosa (AN), bulimia nervosa (BN), and eating disorder not otherwise specified (EDNOS). AN is characterized by obsessive fear of weight gain, severe eating restriction, low body weight, and amenorrhea in women. BN can occur at any body weight and is characterized by episodes of binge-eating - the uncontrolled consumption of large quantities of food in a very short period of time and compensatory weight-loss behaviors. Some investigators have defined EDNOS as atypical eating disorders and refer to them as those conditions that meet the definition of an eating disorder but not the criteria for AN or BN. Finally, binge eating disorder (BED) accounts for a large proportion of individuals categorized as EDNOS ${ }^{1}$ and it is also characterized by episodes of binge-eating except that the individuals do not use any form of compensatory behaviors (i.e. vomiting, laxatives, fasting, etc.). In addition, the prevalence of overweight or obesity is elevated in individuals with BED. ${ }^{2}$

The average estimate of the current prevalence of $A N$ is 280 per 100,000 young females (i.e., 0.28\%). The average current prevalence of BN among young females, using strict diagnostic criteria, is about 1,000 per 100,000 (i.e. $1.0 \%$ ). ${ }^{3}$ Community-based studies have generated prevalence figures for $B E D$ in the region of $2-3 \%$ of the adult population and $8 \%$ of the obese population. Higher rates of BED (20-40\%) have been reported in obese patients seeking weight loss treatment. ${ }^{2}$ AN has the highest mortality rate among psychiatric disorders - $5 \%$ per decade. ${ }^{4}$ It is also grossly elevated in comparison to individuals with no AN. A review (not a meta-analysis) of 60 outcome studies on BN reported a crude mortality rate of $0.3 \% .^{5}$ The mortality risk associated with bulimia nervosa is likely to be elevated, although the actual morbidity and mortality associated with BN remains unclear and deserves future research. ${ }^{6}$ As for BED, mortality risk is associated with the health consequences of overweight and obesity, although recent findings show that negative health effects of binge eating appear to be independent of obesity risk. ${ }^{7}$

Over the past 30 years, eating disorders have generally been conceptualized as almost exclusively determined by environmental factors such as family dynamics ${ }^{8-9}$ or cultural influences from the media (e.g., societal pressures toward the slender ideal). ${ }^{10}$ The idea that eating disorders were merely culture-bound syndromes was predominant until recently, but multiple lines of research findings are challenging the exclusive causal role of socio-cultural influences. In clinical samples, eating disorders are strongly associated with various other categories of psychopathological disturbance such as mood, anxiety, substanceuse and personality disorders, meaning that particular psychiatric disorders or traits might represent expressions of a shared genetic diathesis. ${ }^{11}$ The influence of genetic factors on the etiology of eating disorders has been demonstrated in both family ${ }^{12-13}$ and twin studies. ${ }^{14-18}$ Molecular genetic studies have also begun to identify areas of the genome and candidate genes that might uniquely influence the risk for eating disorders. ${ }^{11,18-24}$

This paper presents a synthesis of the current knowledge about the genetic factors implicated in the etiology of eating disorders. The unique implications of conducting genetic studies on populations that represent a mixture of different ancestries will be also addressed as patterns of genetic influence and heritability might be influenced by cultural and ethnic factors. The goals of this paper are two-fold: first, to review the state of science relevant to genetic research in eating disorders and second, to highlight issues that are unique to the translation and development of genetic research in eating disorders in Brazil and other admixed populations.

\section{Family and twin studies}

Family studies are designed to elucidate if a certain disorder runs in families. This is often the first step in determining whether genes may influence a specific disorder. It has long been known that $A N$ and $B N$ cluster in families and controlled family studies suggest that relatives of probands with eating disorders have approximately a ten-fold greater lifetime risk of having the disorders than relatives of unaffected controls. ${ }^{12,25-}$ ${ }^{26}$ Evidence of familial aggregation emerged for both $A N$ and $\mathrm{BN}$, with a higher relative risk for AN. ${ }^{12-13,25,27}$ Furthermore, additional studies ${ }^{12-13,25,28}$ have demonstrated co-aggregation of the two disorders, indicating possible shared familial vulnerabilities across eating disorders. It is also worth mentioning that there is a higher risk for a range of eating disorders in relatives of individuals with eating disorders rather than a disorder-specific pattern of familial aggregation. ${ }^{12-13,25}$

Family studies are incapable of separating the genetic and environmental components of transmission. Twin studies, in contrast, are able to decompose variance in liability to a trait into independent genetic and environmental sources and provide estimates of their relative magnitude. Since monozygotic twins (MZ) are assumed to be genetically identical, any differences between a pair of $M Z$ twins result from environmental influences. In contrast, differences between dizygotic twins (DZ) could be due to either genetic or environmental influences. Thus, comparing the similarity of $\mathrm{MZ}$ twins and DZ twins provides information about the relative contributions of genetic and environmental factors in the etiology of the disorder. Twin studies on eating disorders have demonstrated that a considerable portion of the observed familiality is due to additive genetic factors. ${ }^{14-16,29}$ Twin studies have estimated the heritability of AN to be between $33 \%$ and $84 \%,{ }^{17}$ and the heritability of BN to be between $28 \%$ and $83 \%{ }^{14}$ with the remaining variance (in both disorders) ascribed to individual specific environmental factors, and negligible impact of shared environmental factors. Many traits related to eating disorders have also a heritable component. These include binge-eating, self-induced vomiting, drive for thinness, dietary restraint and dishinibition. ${ }^{14}$ Data from the Virginia Twin Registry generated heritability estimates for binge eating and vomiting of $46 \%$ and $70 \%$, respectively. ${ }^{30}$

Some basic concepts of genetics need to be introduced. Heritability is the proportion of the population variation in a trait (e.g., body mass index) that can be explained by genetic factors. Additive genetic factors refer to the impact of several genes of small to moderate effect on liability to the trait under study. Shared environment refers to environmental facts to which both members of a twin pair are exposed such as socioeconomic status, religion or origin, parental rearing style. Shared environmental factors contribute to similarities between members of a twin pair. Unique environment refers to environmental circumstances that are experienced by only one member of a twin pair. The estimate of unique environment also includes measurement error.

\section{Association and linkage studies}

The acknowledgement that eating disorders have in part a genetic basis has led to molecular studies aimed at finding 
genetic vulnerability factors. Association studies compare cases that display a trait of interest with controls who do not display the trait, and genotype all individuals for a candidate gene or genes that are hypothesized to be of relevance to the phenotype. Statistical analysis compares genotype frequencies in cases versus controls. ${ }^{31}$ The association approach is the most appropriate when there is substantial prior knowledge of the pathophysiology of a trait that could suggest specific candidate genes. Where the pathophysiology of a disease is not well understood, finding a susceptibility gene using the candidate gene approach alone may involve as much luck as judgment. A false positive result can occur, however, in an admixed or stratified population if a trait is more prevalent in one ethnic group and if the frequency of the genetic marker also differs by ethnicity. There is also the risk of a false positive finding due to multiple statistical tests given the enormous number of genes in the human genome and the increasing easiness to obtain genotypes. ${ }^{32}$

Linkage analysis requires a large sample of multiplex pedigrees or extreme sibling pairs (pairs that are concordant for high values, low values, or extremely discordant pairs for the trait). ${ }^{33}$ Anonymous genetic markers scattered across the genome are used to identify chromosomal regions harboring genes that influence the trait of interest. If the marker and the disease loci are adjacent, then the offspring who inherited the disease gene should have also inherited the same allele at the marker locus. The shared marker allele is "identical by descent" to indicate that the alleles observed in the children are copies of the same parental allele. If a particular locus is involved in susceptibility to the disorder under study, then pairs of siblings with that disease should inherit the same copy of that locus more often than expected by chance. Linkage studies help in narrowing the search space on the human genome. Candidate genes located under the linkage peaks can be further explored using association approaches to determine whether they may actually be associated with the target trait.

The current literature describing the associations between candidate genes and eating disorders has sporadically rendered significant and frequently unreplicated findings. ${ }^{21-22}$ Candidate gene studies in eating disorders have so far focused on genes encoding proteins implicated in the regulation of feeding and body composition, and genes involved in neurotransmitter pathways regulating behavior. Genes implicated in the serotonergic neurotransmission have also been evaluated because of the potency of serotonin as an appetite suppressant and its involvement in some of the traits associated with eating disorders such as obsessive and perfectionist behavior. ${ }^{34-37}$ Promising research areas include the genetics of feeding and weight regulation and the serotonergic system. Positive findings on agouti-related protein gene, ${ }^{38}$ and uncoupling proteins ${ }^{39}$ require replication. Several studies on serotonin receptors have been conducted and produced conflicting results: serotonin receptor 2A, ${ }^{40-44}$ serotonin receptor $2 \mathrm{C}^{45-46}$ and serotonin transporter gene, ${ }^{47-48}$ have been associated with eating disorders susceptibility but several studies failed to replicate these findings. ${ }^{37,49-55}$ The importance of the catecholinergic system in the etiology of eating disorders have been recently stimulated by positive findings for the norepinephrine transporter gene. ${ }^{56-}$ 57 Another unreplicated association study in AN includes the catechol-O-methyl transferase. ${ }^{58}$ The brain-derived neurotrophic gene (BDNF) has also been examined for its association with eating disorders, suggesting its participation in the genetic susceptibility to eating disorders, mainly restricting anorexia nervosa. ${ }^{59-60}$ Conflicting results have also emerged in regard to the role of estrogen pathway genes in the etiology of anorexia nervosa. ${ }^{61-62}$ A recent study, ${ }^{63}$ reporting a significant association between the estrogen receptor beta and bulimia nervosa, implies that this gene (or linked genes) may be involved in the etiology of the disorder. These findings are particularly interesting because the estrogen beta receptor gene is located in a region of the chromosome 14 that showed suggestive linkage with bulimia nervosa. ${ }^{19}$

Branson and coworkers reported a strong association between BED and variants in the melanocortin-4 receptor gene (MC4R). ${ }^{64}$ They identified 24 carriers of MC4R variants among 469 severely obese patients. Stringently diagnosed BED was present in all $20(100 \%)$ of the 24 obese carriers of MC4R variants in contrast to only $14.2 \%$ among those 120 obese non-carriers matched for age, sex and body mass index (BMI). Their findings were not replicated by Hebebrand and colleagues who investigated a group of 814 obese children and adolescents and identified 43 carriers of MC4R mutations. ${ }^{65}$ No evidence for an increased rate of binge-eating behavior in obese carriers of MC4R mutations was found. MC4R variants might also be associated with poor treatment outcome in severely obese individuals who undergo laparoscopic gastric banding. ${ }^{66}$

Additional research is still needed for other candidate genes involved in the neurotransmitter system (e.g., dopamine, glutamate, opioids) and also in the regulation of feeding and energy expenditure (e.g., agouti-related protein, neuropeptide $Y$, leptin and reproductive hormones).

The Price Foundation of Geneva, Switzerland, funded a series of studies that have rendered intriguing linkage results for both anorexia and bulimia nervosa. A number of clinical sites through North America and Europe were involved in this cooperative effort. These studies illustrated the importance of changing the current nosology to better reflect the underlying structure of eating disorders implying accurate phenotyping in order to reduce phenotypic and genotypic heterogeneity. Miguel et al. ${ }^{67}$ have also addressed the importance of elucidating specific homogeneous subgroups in genetic studies of other psychiatric disorders such as obsessive-compulsive disorder (OCD). These authors highlight that this approach might help identify subtypes of the disorder under investigation distinctively transmitted within families due to unique genetic factors and, therefore, more easily identified with genetic linkage studies. Kaye and colleagues described the methodology for the first linkage study of AN of 192 families with at least one affected relative pair with $A N$ and related eating disorders. ${ }^{68}$ The initial findings showed no linkage. However, two additional approaches yielded significant linkage. First, the authors restricted the linkage analysis to a subset of families in which at least two affected relatives had a diagnosis of the prototypic AN phenotype - restricting AN. This approach was relevant as heterogeneity in a sample can reduce underlying linkage signals. Restricting AN represents a uniquely recognizable phenotype and one that is quite plausibly influenced by heritable biological factors. Limiting the linkage analysis to the restricting AN subset produced evidence for the presence of a susceptibility locus in chromosome $1 .{ }^{20}$ In addition, Devlin et al. ${ }^{18}$ selected and incorporated core behavioral covariates (drive for thinness and obsessionality). The inclusion of these covariates revealed several regions of interest in chromosomes 1,2 and 13. Accurate phenotyping in genetic analysis is crucial in the process of identifying genes that contribute for the liability of psychiatric conditions. 
The only published linkage study of BN reported significant linkage in chromosome $10^{19}$ when using a broad sample of families with BN. A second peak occurred further p-ter (terminal end of the short arm of the chromosome), which approached significance. Suggestive linkage was also observed in chromosome 14. Phenotypic information was incorporated in the linkage analysis through focusing on families who had elevated rates of vomiting. This phenotype was chosen because twin studies in $\mathrm{BN}$ had indicated that vomiting was particularly heritable (72\%). ${ }^{69}$ Significant linkage was observed in this analysis in the cohort enriched for vomiting in chromosome 10. Another area suggestive of linkage was identified in chromosome 14.

This team of researchers has begun to explore the regions under the linkage peaks for rational candidate genes. ${ }^{70}$ Both serotonin $1 \mathrm{D}$ and delta opioid receptor genes exhibited significant association with AN. Future studies should investigate the role of these receptor genes in the etiology of AN, possible differential association with subtypes of AN, and interactions between these genes and other genes involved with serotonergic and opiodergic function and metabolism. ${ }^{70}$

\section{Genetic research in Brazil: understanding population admixture}

Gene flow between subpopulations generates chromosomes made up of segments that have ancestry from different subpopulations. The admixture proportions of an individual are defined as the proportions of the individual's genome that have ancestry from each subpopulation. ${ }^{71}$ Studying admixture is important from a historical and anthropological perspective. Migration of individuals and populations (and subsequent mixing) has always played an important role in the evolutionary history of humans. Since the $15^{\text {th }}$ century, these migrations have occurred on a larger scale. In the case of the Americas, populations that were previously isolated for generations came into contact, and many persons living in North, Central and South America can trace their ancestry to different continents.

Brazilians represent one of the most heterogeneous populations in the world, resulting from five centuries of interethnic mating of Portuguese colonizers, African slaves and the native Amerindians. ${ }^{72-73}$ The Portuguese-Amerindian admixture, mating between European men and indigenous women, began right after the arrival of the first colonizers. After 1755 , it was even stimulated in order to increase the population and the colonial occupation of the land. ${ }^{74}$ The native indigenous tribes went through a significant demographic decline due to conflicts with the colonizers and maladies to which they were not adapted. ${ }^{72,75}$ Africans were forcefully brought to Brazil in the middle of the $16^{\text {th }}$ century, as slaves, to work on sugarcane cultivation and, later on, in the extraction of gold and gemstones and on coffee plantations.

Approximately half a million Portuguese came to Brazil between 1500 and 1808, and around 3.5 million Africans arrived in Brazil during the years of slave trade, between 1551 and $1850 .{ }^{75}$ After the Brazilian ports were legally opened to all friendly nations, the country received immigrants from several parts of the world. According to Callegari-Jacques and Salzano, ${ }^{76} 58 \%$ of the immigrants who arrived in Brazil between 1500 and 1972 were Europeans, 40\% were Africans, and $2 \%$ were Asians.

Brazilians refer to color as a synonym for race, based on complex phenotypic assessments that take into account, besides skin pigmentation, other physical characteristics such as hair type, nose and lip shape. Color is probably preferred to race in Brazil because it encompasses the continuous aspects of phenotypes. ${ }^{77}$ The Brazilian emphasis on physical appearance rather than ancestry is demonstrated by the fact that the national demographic census usually includes five self-reported categories of color. People report whether they are white, black, mixed, yellow or indigenous. The 2000 national census revealed that $53 \%$ of the population (out of 170 million people) declared themselves white, 38\% mixed, $7 \%$ black, .5\% yellow, $0.4 \%$ indigenous and $0.7 \%$ did not report their color or race. ${ }^{78}$ With the history of five centuries of interethnic mating it is very unlikely that the color of a Brazilian person predicts his/ her genomic ancestry.

This history of migrations and admixture can be reconstructed and interpreted using genetic markers. A useful perspective can be obtained when analyzing chromosomal markers, maternally transmitted mtDNA markers and Y-chromosome specific markers, which are transmitted from fathers to sons. Thus, using genetic markers we can reconstruct history at the individual and population level, even in the absence of a historical record.

The study of DNA lineage markers to ascertain the continental ancestry of Brazilian white individuals demonstrated that the vast majority of $Y$ chromosomes in white Brazilian males, regardless of their regional source, were of European origin, with a very low frequency of sub-Saharan African Y chromosomes and a complete absence of Amerindian contribution. ${ }^{79}$ On the other hand, by analyzing mtDNA, a surprising high amount of $33 \%$ Amerindian and $28 \%$ African contribution to the total mtDNA pool of white Brazilians was found. ${ }^{80}$

Brazil is a large territory and because different population groups moved into diverse parts of the country, there is considerable phylogeographical heterogeneity. mtDNA was analyzed in the four main regions of Brazil and it was found there was broad agreement with what could be expected from historical data: a predominance of Amerindian matrilineages in the Amazon region in the north, a preponderance of African lineages in the northeast, equal proportions in the southeast, and European predominance in the south. The most pronounced levels of admixture were observed in the northeast and southeast. ${ }^{80}$ Together, these results confirm historical records of directional mating in Brazil involving European males and Amerindian and African females. In addition to the role that these studies play in understanding Brazilian history, studying admixture has important applications in the biomedical field as discussed below.

\section{Studying complex traits: population stratification and admixture mapping}

In the view of classical genetics, diseases are divided into Mendelian disorders and complex traits. While the former are attributed to single gene mutations with a single mode of inheritance, the latter are thought to result from multiple genes, each playing a small and interactive role in the susceptibility to the diseases. ${ }^{81}$ But discrepancy in results could also be attributed, at least partially, to the presence of residual population stratification.

The case-control design is a widely used approach for investigating associations between candidate genes and dichotomous disease traits. Associations between genotype and outcome may be confounded by unrecognized population stratification. In general, population stratification exists when 
the total population has been formed by admixture between subpopulations and when admixture proportions (defined as the proportions of the genome that have ancestry from each subpopulation) vary between individuals. If the risk of disease varies with admixture proportions, this will confound associations of disease with genotype at any locus where allele frequencies vary between subpopulations. In other words, population stratification exists if the gene under study shows marked variation in allele frequency across subgroups of population and if these subgroups also differ in their baseline risk of the disease. This kind of bias will always increase the chances of a false-positive significance test if the candidate gene has no causal effect on the risk of disease. What is at issue is how much variation in allele frequencies and disease rates there is between subdivisions of the major ethnic categories. ${ }^{82}$

Part of the concern about the potential magnitude of the population stratification problem derives from the observation that the literature on candidate gene associations is marked by a high frequency of non-replication studies. ${ }^{82}$ Critical methodological components to these failures are small sample sizes and lack of dense genotyping. But at least some of the discrepancy in results could be imputed to residual population stratification.

The concern with population stratification would be diminished by careful attention to the principles of epidemiological study design, including the selection of controls that are representative of the source population of cases and by making some effort to control ethnicity by restriction, matching, or stratified or multivariate analysis. If the confounder - admixture proportions - can be measured accurately, control can be achieved by modeling its effects in the analysis. More detailed information on ethnicity is necessary, meaning that individuals must be allocated to the finest ethnic origin categories that can reliably be determined, and individuals from mixed-ethnicity families must be treated appropriately. ${ }^{82}$

No candidate gene association should be considered "confirmed" until replicated at least by multiple well-designed studies in different populations where any effects of population stratification or other methodological biases are unlikely to act in a consistent manner.

The genetic structure of admixed human populations could be explored to localize genes that underlie ethnic variation in diseases or traits of interest. This approach is named "admixture mapping". ${ }^{71}$ Whole-genome scanning under the admixture mapping strategy consists of scanning the genome and identifying the regions with an excess of one ancestry in the cases versus the controls assuming that this ancestry carries the predisposing allele. ${ }^{83}$ As compared to association studies, admixture mapping has two key advantages: it typically requires only 2,000-3,000 ancestry-informative markers for a genome search (compared with at least 350,000 markers for wholegenome association studies) and it is less susceptible to allelic heterogeneity. The ability to detect a disease locus depends only on whether the pool of high-risk alleles is differentially distributed between subpopulations; it does not matter whether there are a few common risk-associated alleles or many rare risk-associated alleles at the locus under study. ${ }^{71}$

Admixture mapping can be applied only when admixture has been occurring at least for two generations. The most obvious applications are to populations formed by admixture between groups originating on different continents that occurred as a result of European maritime expansion during the past few hundred years, Brazilians being a good example.

There are not many diseases for which epidemiological criteria support genetic explanations for ethnic variation in risk, but include some of the leading causes of morbidity and mortality, such as type 2 diabetes, hypertension, obesity, and coronary disease.

Implications for the genetic research of eating disorders in Brazil

The most rigorous genetic studies of anorexia nervosa and bulimia nervosa have been conducted with relatively homogeneous populations with samples selected to represent only one ethnic group. Hence, the heritability of these disorders among different ethnic groups is unknown.

If a broader understanding of the genetic contribution to the etiology of eating disorders is to be pursued, the unique implications to start a large-scale study of eating disorders genetics in a country like Brazil need to be addressed.

Collaborative efforts are of utmost importance. Under the coordination of a principal investigator and the funding provided by a governmental or private institution, the number and location of sites need to be determined and contacted to get their collaboration. Several factors need to be carefully evaluated: the availability of trained academic collaborators who are experienced in assessing eating-disordered individuals in order to establish consistent behavioral assessment procedures across sites and the sites must have a significant number of records of individuals who had been previously treated for eating disorders. Therefore it will be possible to contact the necessary number of subjects who had previously been in treatment at the eating disorders treatment centers. The history of the treatment of eating disorders in Brazil dates back in the late 80's when academic centers started their programs located in Sao Paulo, Rio de Janeiro and Porto Alegre. New eating disorders treatment centers in other areas of the country are beginning to develop and contact with these new centers is crucial to address the possibility of having their collaboration to recruit individuals who are representative of other Brazilian regions.

The core site, with the help of the other sites, will develop a protocol for ascertaining individuals with eating disorders and controls, including psychological evaluations, collecting blood samples for DNA analysis, and obtaining informed consent. The protocol has to be separately approved by each site's Ethics Committee. Following informed consent and completion of all assessment procedures, research participants will give peripheral blood samples that will be stored at the core site's molecular genetic laboratory for DNA extraction, genotyping, and quantitative genetic analysis. Such a project has already been developed through a cooperative arrangement between the Price Foundation, the University of Pittsburgh, and other academic sites in North America and Europe, resulting in the largest research on the genetics of eating disorders. The experience obtained by these investigators can be helpful in carrying out a similar project in Latin America.

As mentioned before, Brazil is a large country with a highly admixed population and the proportions of admixture vary across different regions (e.g., Rio de Janeiro and Sao Paulo are large cities located in the southeastern region where levels of admixture are higher than in Porto Alegre, which is located in the south of Brazil). In order to avoid population stratification in this situation, it would be best to conduct the genetic 
research in only one of the Brazilian regions where the levels of admixture are known (it is not possible to limit data collection to one ethnic group since there is not such a group in this country). On the other hand, it is important to consider the low prevalence of eating disorders, which means a very long period to obtain an appropriate sample size if data collection is limited to only one geographic region.

Would Brazilian participants be able to accurately report their ancestry information? Certainly not after five centuries of interethnic crosses. A study of Parra et al. demonstrated that at the individual level there was significant dissociation of skin color, determined by physical evaluation, and African ancestry, estimated by molecular markers. ${ }^{77}$ This study shows that, in Brazil, people might be classified on the basis of the presence of certain alleles at a small number of genes that have impact on the physical appearance, while ignoring all the rest of the genome. It also points to the fact that the allocation of research participants to the finest ethnic origin cannot be reliably determined.

In a linkage study of complex traits such as eating disorders, population isolates offer distinct advantages over large out bred populations. They tend to exhibit stronger disequilibrium, which makes disequilibrium mapping a promising search technique. Also, because of founder effects, the number of genes underlying a trait is presumably smaller in such populations. Brazilian population is the opposite of a population isolate with high admixture and high allelic heterogeneity. This might have an important disadvantage for the mapping of susceptibility alleles as compared to population isolates in linkage studies. Also important genes in population isolates may be unimportant in other populations, limiting comparison of results among studies with population isolates and admixed groups.

In the case of an association study, if the idea is to ascertain participants from different areas of the country in order to obtain a large sample, then genomic information should be made available. Ancestry-informative markers will be necessary to accurately measure the admixture proportions of the individuals and control for it as a confounder. Tests for allelic association with the disease can then be adjusted for the confounder in this kind of study. For example, African American and Hispanic American populations have been investigated by means of admixture mapping in the study of hypertension and type 2 diabetes where confounding by populations stratification was made possible by using a panel of markers informative for ancestry and Bayesian computationally intensive methods for statistical analysis. ${ }^{83-84}$ The genetics of complex traits is yet to be investigated in other countries with such admixed populations by means of admixture mapping.

In summary, the genetic research of eating disorders in Brazil faces many challenges. The first relates to the high cost of this kind of research and to the fact that it is very timeconsuming, along with the need to get various eating disorders centers to cooperate, with different levels of clinical and research expertise among the first centers in Sao Paulo, Rio de Janeiro and Porto Alegre compared to the new centers. The technical issues refer to the specifics of genetic research with such an admixed population and the strategies to be utilized in order to overcome these difficulties.

The future of eating disorders genetics research: Brazil and Latin America

During the past 15 years, our ideas on the etiology of eating disorders have gone through a major revolution. The field is now compelled to integrate the knowledge of the role of genetics along with social, psychological and family factors to understand the risk for these disorders. It is also clear, that until now, consistent genetic research in eating disorders has been developed in Europe and North America. The development of a genetic research project in other countries is essential and will integrate a new perspective in the biological etiology of eating disorders. As very large samples are necessary to avoid false negative results, and case finding in eating disorders is particularly challenging, it becomes clear that a major collaborative genetics initiative not only in Brazil, but also in Latin America would represent the realistic possibility of studying the genetics of eating disorders in the context of inter ethnic groups. Since there is wide agreement among human geneticists and anthropologists that, from a biological standpoint, human races do not exist, ${ }^{77}$ this kind of research might be relevant to improve the knowledge of complex traits such as eating disorders once it might represent an approach that brings genetic and cultural (in this case, different ancestries) factors together.

\section{Acknowledgements}

This paper was the result of a collaborative work between Department of Psychiatry - University of North Carolina, Chapel Hill and Department of Psychiatry, Paulista Medical School, Universidade Federal de Sao Paulo (UNIFESP), São Paulo (SP), Brazil.

\section{References}

1. American Psychiatric Association. Diagnostic and Statistical Manual of Mental Disorders. 4th ed. Washington, DC: American Psychiatric Press; 1994.

2. Grilo CM. Binge eating disorder. In: Fairburn CG, Brownell KD, eds.. Eating disorders and obesity - A comprehensive handbook. New York: Guilford Press; 2002. p. 178-82.

3. Hoek HW. Distribution of eating disorders. In: Fairburn CG, Brownell $K D$, editors. Eating disorders and obesity - A comprehensive handbook. New York London: The Guilford Press; 2002. p. 233-7.

4. Sullivan PF. Mortality in anorexia nervosa. Am J Psychiatry. 1995;152(7): 1073-4.

5. Keel P, Mitchell J. Outcome in bulimia nervosa. Am J Psychiatry. 1997; 154(3):313-21

6. Herzog D, Greenwood D, Dorer D, Flores A, Ekeblad E, Richards A, Blais MA, Keller MB . Mortality in eating disorders: a descriptive study. Int J Eat Disord. 2000;28(1):20-6.

7. Reichborn-Kjennerud T, Bulik C, Sullivan PF, Tambs K, Harris $J R$. Psychiatric and medical symptoms in binge eating in the absence of compensatory behaviors. Obes Res. 2004;12(9): 1445-54.

8. Sours JA. The anorexia nervosa syndrome. Int J Psychoanal. 1974;55(4):567-79.

9. Minuchin S, Rosman BL, Baker L. Psychosomatic families: anorexia nervosa in context. Cambridge, MA: Harvard University Press; 1978.

10. Garner DM, Garfinkel PE. Socio-cultural factors in the development of anorexia nervosa. Psychol Med. 1980;10(4):647-56.

11. Klump KL, Kaye WH, Strober M. The evolving genetic foundations of eating disorders. Psychiatr Clin North Am. 2001;24(2):215-25.

12. Lilenfeld LR, Kaye WH, Greeno CG, Merikangas KP, Plotnicov K, Pollice C, Rao R, Strober M, Bulik CM, Nagy L. A controlled family study of anorexia nervosa and bulimia nervosa:psychiatric disorders in first-degree relatives and effects of proband comorbidity. Arch Gen Psychiatry. 1998;55(7):603-10.

13. Strober M, Freeman R, Lampert C, Diamond J, Kaye W. Controlled family study of anorexia and bulimia nervosa: evidence of shared liability and transmission of partial syndromes. Am J Psychiatry. 2000;157(3):393-401

14. Bulik CM, Sullivan PF, Wade TD, Kendler KS. Twin studies of eating disorders: a review. Int J Eat Disord. 2000;27(1):1-20. 
15. Kendler KS, MacLean C, Neale M, Kessler R, Heath A, Eaves L. The genetic epidemiology of bulimia nervosa. Am J Psychiatry. $1991 ; 148(12): 1627-37$

16. Wade TD, Martin NG, Neale MC, Tiggemann M, Treloar SA, Bucholz KK, Madden PA, Heath AC. The strucuture of genetic and environmental risk factors for three measures of disordered eating. Psychol Med. 1999;29(4):925-34.

17. Wade TD, Bulik CM, Neale M, Kendler KS. Anorexia nervosa and major depression: shared genetic and environmental risk factors. Am J Psychiatry. 2000;157(3):469-71.

18. Devlin B, Bacanu SA, Klump KL, Bulik CM, Fichter MM, Halmi KA, Kaplan AS, Strober M, Treasure J, Woodside DB, Berrettini WH, Kaye WH. Linkage analysis of anorexia nervosa incorporating behavioral covariates. Hum Mol Genet. 2002;11(6):689-96.

19. Bulik CM, Devlin B, Bacanu SA, Thornton L, Klump KL, Fichter MM, Halmi KA, Kaplan AS, Strober M, Woodside DB, Bergen AW Ganjei JK, Crow S, Mitchell J, Rotondo A, Mauri M, Cassano G, Keel $\mathrm{P}$, Berrettini WH, Kaye WH. Significant linkage on chromosome $10 p$ in families with bulimia nervosa. Am J Hum Genet. 2003; 72(1):200-7.

20. Grice DE, Halmi KA, Fichter MM, Strober M, Woodside DB, Treasure JT, Kaplan AS, Magistretti PJ, Goldman D, Bulik CM, Kaye WH, Berrettini WH. Evidence for a susceptibility gene for anorexia nervosa on chromosome 1. Am J Hum Genet. 2002;70(3):787-92.

21. Bulik CM, Tozzi F. Contemporary thinking about the role of genes and environment in eating disorders. Epidemiol Psichiatr Soc. 2004;13(2):91-8.

22. Bulik CM, Tozzi F. Genetics in eating disorders: state of the science. CNS Spectr. 2004;9(7):511-5.

23. Bulik CM, Tozzi F. The genetics of bulimia nervosa. Drugs Today (Barc). 2004;40(9):741-9.

24. Hinney A, Friedel S, Remschmidt H, Hebebrand J. Genetic risk factors in eating disorders. Am J Pharmacogenomics. $2004 ; 4(4): 209-23$

25. Hudson JI, Pope HG, Jonas JM, Yurgelun-Todd D, Frankenburg FR A controlled family history study of bulimia. Psychol Med. 1987;17(4):883-90.

26. Kassett JA, Gershon ES, Maxwell ME, Guroff JJ, Kazuba DM, Smith $A L$, Brandt HA, Jimerson DC. Psychiatric disorders in the firstdegree relatives of probands with bulimia nervosa. Am J Psychiatry. 1989;146(11):1468-71.

27. Mangweth B, Hudson. JI, Pope HG, Hausmann A, De Col CD, Laird NM, Beibl W, Tsuang MT. Family study of the aggregation of eating disorders and mood disorders. Psychol Med. 2003;33(7):1319-23.

28. Gershon ES, Schreiber JL, Hamovit JR, Dibble ED, Kaye W Nurnberger $\mathrm{JI} \mathrm{Jr}$, Andersen AE, Ebert M. Clinical findings in patients with anorexia nervosa and affective illness in their relatives. Am J Psychiatry. 1984;141(11):1419-22.

29. Walters EE, Kendler KS. Anorexia nervosa and anorexia-like syndromes in a population-based female twin sample. Am J Psychiatry. 1995;152(1):64-71.

30. Kendler KS, McLean C, Neale M, Kessler R, Heath A, Eaves L. The genetic epidemiology of bulimia nervosa. Am J Psychiatry. $1991 ; 148(12): 1627-37$.

31. Sham P. Statistics in human genetics. London, England: Arnold; 1998.

32. Sullivan PF, Eaves LJ, Kendler KS, Neale MC. Genetic case-control association studies in neuropsychiatry. Arch Gen Psychiatry. 2001;58(11):1015-24

33. Allison D, Heo M, NJ S, Wong S, Elston RC. Extreme selection strategies in gene mapping studies of oligogenic quantitative traits do not always increase power. Hum Hered. 1998;48(2):97-107.

34. Ziegler A, Hebebrand J, Gorg T, Rosenkranz K, Fichter M, HerpertzDahlmann B, Remschmidt H, Hinney A. Further lack of association between the 5-HT2A gene promoter polymorphism and susceptibility to eating disorders and a meta-analysis pertaining to anorexia nervosa. Mol Psychiatry. 1999;4(5):410-2.

35. Sundaramurthy D, Pieri LF, Gape H, Markham AF, Campbell DA Analysis of the serotonin transporter gene linked polymorphism (5-HTTLPR) in anorexia nervosa. Am J Med Genet. $2000 ; 96(1): 53-5$.
36. Ando T, Komaki G, Karibe M, Kawamura N, Hara S, Takii M, Naruo T, Takei M, Kurokawa N, Nozoe S, Kubo C, Komaki G. 5-HT2A promoter polymorphism is not associated with anorexia nervosa in Japanese patients. Psychiatr Genet. 2001;11:157-60.

37. Karwautz A, Rabe-Hesketh S, Hu X, Zhao J, Sham P, Collier DA, Treasure JL. Individual-specific risk factors for anorexia nervosa: a pilot study using a discordant sister-pair design. Psychol Med. 2001;31(2):317-29.

38. Vink T, Hinney A, van Elburg AA, van Goozen SH, Sandkuijl LA, Sinke RJ, Herpertz-Dahlmann BM, Hebebrand J, Remschmidt H, van Engeland $\mathrm{H}$, Adan RA. Association between an agouti-related protein gene polymorphism and anorexia nervosa. Mol Psychiatry. $2001 ; 6(3): 325-8$

39. Campbell DA, Sundaramurthy D, Gordon D, Markham AF, Pieri LF. Association between a marker in the UCP-2/UCP-3 gene cluster and genetic susceptibility to anorexia nervosa. Mol Psychiatry. 1999;4(1):68-70.

40. Collier DA, Arranz MJ, Li T, Mupita D, Brown N, Treasure J. Association between 5-HT2A gene promoter polymorphism and anorexia nervosa. Lancet. 1997;350(9075):412.

41. Enoch MA, Kaye WH, Rotondo A, Greenberg BD, Murphy DL, Goldman D. 5-HT2A promoter polymorphism-1438G/A, anorexia nervosa, and obsessive-compulsive disorder. Lancet. 1998;351(9118):1785-6.

42. Sorbi S, Nacmias B, Tedde A, Ricca V, Mezzani B, Rotella CM. 5HT2A promoter polymorphism in anorexia nervosa. Lancet. 1998;351(9118):1785.

43. Nacmias B, Ricca V, Tedde A, Mezzani B, Rotella CM, Sorbi S. 5HT2A receptor gene polymorphisms in anorexia nervosa and bulimia nervosa. Neurosci Lett. 1999;277(2):134-6.

44. Ricca V, Nacmias B, Cellini E, Bernardo MD, Rotella CM, Sorbi S. 5-HT2A receptor gene polymorphism and eating disorders. Neurosci Lett. 2002;323(2):105-8.

45. Westberg L, Bah J, Rastam M, Gillberg C, Wentz E, Melke J, Hellstrand M, Eriksson E. Association between a polymorphism of the $5 \mathrm{HT} 2 \mathrm{C}$ receptor and weight loss in teenage girls. Neuropsychopharmacology. 2002;26(6):789-93.

46. Hu X, Giotakis O, Li T, Karwautz A, Treasure J, Collier DA. Association of 5-HT2c gene with suscetibility and minimum body mass index in anorexia nervosa. Neuroreport. 2003;14(6):781-83.

47. Bella DD, Catalano M, Cavallini MC, Riboldi C, Bellodi L. Serotonin transporter linked polymorphic region in anorexia nervosa and bulimia nervosa. Mol Psychiatry. 2000;5(3):233-4.

48. Fumeron F, Betoulle D, Aubert R, Herbeth B, Siest G, Rigaud D. Association of a functional 5-HT transporter gene polymorphims with anorexia nervosa and food intake. Mol Psychiatry. 2001;6:9-10.

49. Hinney A, Barth N, Ziegler A, von Prittwitz S, Hamann A, Hennighausen K, Pirke KM, Heils A, Rosenkranz K, Roth H, Coners H, Mayer H, Herzog W, Siegfried A, Lehmkuhl G, Poustka F, Schmidt $\mathrm{MH}$, Schafer H, Grzeschik KH, Lesch KP, Lentes KU, Remschmidt $H$, Hebebrand J. Serotonin transporter gene-linked polymorphic region: allele distributions in relationship to body weight and in anorexia nervosa. Life Sci. 1997;61(21):PL 295-303.

50. Hinney A, Ziegler A, Nothen MM, Remschmidt H, Hebebrand J. 5HT2A receptor gene polymorphisms, anorexia nervosa, and obesity. Lancet. 1997;350(9087):1324-5.

51. Campbell DA, Sundaramurthy D, Markham AF, Pieri LF. Lack of association between 5-HT2A gene promoter polymorphism and susceptibility to anorexia nervosa. Lancet. 1998;351(9101):499.

52. Burnet PW, Smith KA, Cowen PJ, Fairburn CG, Harrison PJ. Allelic variation of the 5-HT2C receptor (HTR2C) in bulimia nervosa and binge eating disorder. Psychiatr Genet. 1999;9(2):101-4.

53. Nishiguchi N, Matsushita S, Suzuki K, Muruyama M, Shirakawa O, Higuchi S. Association between 5HT2A receptor gene promoter polymorphism and eating disorders in Japanese patients. Biol Psychiatry. 2001;50(2):123-8

54. Gorwood P, Ades J, Bellodi L, Cellini E, Collier DA, Di Bella D, Di Bernardo M, Estivill X, Fernandez-Aranda F, Gratacos M, Hebebrand J. Hinney A, Hu X, Karwautz A, Kipman A, Mouren-Simeoni MC, Nacmias B, Ribases M, Remschmidt H, Ricca V, Rotella CM, Sorbi $\mathrm{S}$, Treasure J, EC Framework in Healthy Eating Consortium. The 5HT(2A) -1438G/A polymorphism in anorexia nervosa: a combined 
analysis of 316 trios from six European centres. Mol Psychiatry. 2002; 7(1):90-4.

55. Urwin RE, Bennetts BH, Wilcken B, Beumont PJ, Russell JD, Nunn $\mathrm{KP}$. Investigation of epistasis between the serotonin transporter and norepinephrine transporter genes in anorexia nervosa. Neuropsychopharmacology. 2003;28(7):1351-5.

56. Urwin RE, Bennetts B, Wilcken B, Lampropoulos B, Beumont P, Clarke S, Russell J, Tanner S, Nunn KP. Anorexia nervosa (restrictive subtype) is associated with a polymorphism in the novel norepinephrine transporter gene promoter polymorphic region. Mol Psychiatry. 2002;7(6):652-7.

57. Urwin RE, Bennetts BH, Wilcken B, Lampropoulos B, Beumont PJ, Russell JD, Tanner SL, Nunn KP. Gene-gene interaction between the monoamine oxidase A gene and solute carrier family 6 (neurotransmitter transporter, noradrenalin) member 2 gene in anorexia nervosa (restrictive subtype). Eur J Hum Genet. 2003;11(12):945-50.

58. Frisch A, Laufer N, Danziger $\mathrm{Y}$, Michaelovsky E, Leor S, Carel C, Stein D, Fenig S, Mimouni M, Apter A, Weizman A. Association of anorexia nervosa with the high activity allele of the COMT gene: a family-based study in Israeli patients. Mol Psychiatry. $2001 ; 6(2): 243-5$.

59. Ribases M, Gratacos M, Fernandez-Aranda F, Bellodi L, Boni C, Anderluh M, Cavallini MC, Cellini E, Di Bella D, Erzegovesi S, Foulon C, Gabrovsek M, Gorwood P, Hebebrand J, Hinney A, Holliday J, Hu X, Karwautz A, Kipman A, Komel R, Nacmias B, Remschmidt H, Ricca V, Sorbi S, Wagner G, Treasure J, Collier DA, Estivill X. Association of BDNF with anorexia, bulimia and age of onset of weight loss in six European populations. Hum Mol Genet. 2004;13(12): 1205-12.

60. Ribases M, Gratacos M, Fernandez-Aranda F, Bellodi L, Boni C, Anderluh M, Cristina Cavallini M, Cellini E, Di Bella D, Erzegovesi S, Foulon C, Gabrovsek M, Gorwood P, Hebebrand J, Hinney A, Holliday J, Hu X, Karwautz A, Kipman A, Komel R, Nacmias B, Remschmidt H, Ricca V, Sorbi S, Tomori M, Wagner G, Treasure J, Collier DA, Estivill X. Association of BDNF with restricting anorexia nervosa and minimum body mass index: a family-based association study of eight European populations. Eur J Hum Genet. 2005; 13(4):428-34.

61. Rosenkranz K, Hinney A, Ziegler A, Hermann H, Fichter M, Mayer $H$, Siegfried W, Young JK, Remschmidt H, Hebebrand J. Systematic mutation screening of the estrogen receptor beta gene in probands of different weight extremes: identification of several genetic variants. J Clin Endocrinol Metab. 1998;83(12):4524-7.

62. Eastwood H, Brown KM, Markovic D, Pieri LF. Variation in the ESR1 and ESR2 genes and genetic suscetibility to anorexia nervosa. Mol Psychiatry. 2002;7:86-9.

63. Nilsson M, Naessen S, Dahlman I, Hirschberg AL, Gustafsson JA, Dahlman-Wright K. Association of estrogen receptor beta gene polymorphisms with bulimic disease in women. Mol Psychiatry. 2004;9(1):28-34.

64. Branson R, Potoczna N, Kral JG, Lentes KU, Hoehe MR, Horber FF. Binge eating as a major phenotype of melanocortin 4 receptor gene mutations. N Eng J Med. 2003;348(12):1096-103.

65. Hebebrand J, Geller F, Demple A, Heinzel-Gutenbrunner M, Raab M, Gerber G, Wermter AK, Horro FF, Blundell J, Schafer H, Remschmidt $\mathrm{H}$, Herpertz S, Hinney A. Binge-eating episodes are not characteristic of carriers of melanocortin-4 receptor gene mutations. Mol Psychiatry. 2004;9:796-800.

66. Potoczna N, Branson R, Kral JG, Piec G, Steffen R, Ricklin T, Hoehe MR, Lentes KU, Horber FF. Gene variants and binge eating as predictors of comorbidity and outcome of treatment in severe obesity. J Gastrointest Surg. 2004;8(8):971-82, discussion: 981-2.

67. Miguel EC, Leckman JF, Rauch S, do Rosario-Campos MC, Hounie AG, Mercadante MT, Chacon P, Pauls DL. Obsessive-compulsive disorder phenotypes: implications for genetic studies. Mol Psychiatry. 2005; 10(3):258-75.

68. Kaye WH, Lilenfeld LR, Berrettini WH, Strober M, Devlin B, Klump KL, Goldman D, Bulik CM, Halmi KA, Fichter MM, Kaplan A, Woodside DB, Treasure J, Plotnicov KH, Pollice C, Rao R, McConaha CW. A search for susceptibility loci for anorexia nervosa: methods and sample description. Biol Psychiatry. 2000;47(9):794-803.
69. Sullivan PF, Bulik CM, Kendler KS. Genetic epidemiology of binging and vomiting. Br J Psychiatry. 1998;173:75-9.

70. Bergen $A W$, van den Bree MB, Yeager M, Welch R, Ganjei JK, Haque K, Bacanu S, Berrettini WH, Grice DE, Goldman D, Bulik CM, Klump K, Fichter M, Halmi K, Kaplan A, Strober M, Treasure J, Woodside $\mathrm{B}$, Kaye WH. Candidate genes for anorexia nervosa in the 1p33-36 linkage region: serotonin 1D and delta opioid receptor loci exhibit significant association to anorexia nervosa. Mol Psychiatry. 2003;8(4):397-406.

71. McKeigue PM. Prospects for admixture mapping of complex traits. Am J Hum Genet. 2005;76(1):1-7.

72. Salzano FM, Freire-Maia N. Problems in human biology: a study of Brazilian populations. Detroit, MI: Wayne State University Press; 1970.

73. Bethell L. Nota sobre as populações americanas às vésperas das invasões européias. In: America Latina colonial. São Paulo: Editora da Universidade de São Paulo; 1997. p. 129-31.

74. Morner M. Race mixture in the history of Latin America. Boston, MA: Little Brown; 1967.

75. Ribeiro D. O povo brasileiro: a formação e o sentido do Brasil. Sao Paulo: Companhia das Letras; 1995.

76. Callegari-Jacques S, Salzano F. Brazilian Indian/non Indian interactions and their effects. Ciencia Cultura, Brasil. 1999;51(3-4):166-74.

77. Parra FC, Amado RC, Lambertucci JR, Rocha J, Antunes CM, Pena SD. Color and genomic ancestry in Brazilians. Proc Natl Acad Sci U S A. 2003;100(1):177-82.

78. IBGE. Censo demográfico 2000: características gerais da população: resultados da amostra - cor ou raça. In: www.ibge.gov.br (acessado em 14.05.05).

79. Carvalho-Silva DR, Santos FR, Rocha J, Pena SD. The phylogeography of Brazilian Y-chromosome lineages. Am J Hum Genet. 2001;68(1):281-6.

80. Alves-Silva J, da Silva Santos M, Guimaraes PE, Ferreira AC, Bandelt $\mathrm{HJ}$, Pena SD, Prado VF. The ancestry of Brazilian mtDNA lineages. Am J Hum Genet. 2000;67(2):441-61. Erratum in: Am J Hum Genet. 2000;67(3):775.

81. Bomprezzi R, Kovanen P, Martin R. New approaches in investigating heterogeneity in complex traits. J Med Genet. 2003;40(8):553-9.

82. Thomas DC, Witte JS. Population stratification: a problem for casecontrol studies of candidate-gene associations? Cancer Epidemiol Biomarkers Prev. 2002;11(6):505-12.

83. Darvasi A, Shifman S. The beauty of admixture. Nat Genet. 2005;37(2): 118-9.

84. Parra EJ, Hoggart CJ, Bonilla C, Dios S, Norris JM, Marshall JA, Hamman RF, Ferrell RE, McKeigue PM, Shriver MD. Relation of type 2 diabetes to individual admixture and candidate gene polymorphisms in the Hispanic American populations od San Luis Valley, Colorado. J Med Genet. 2004;41(11):e116. 